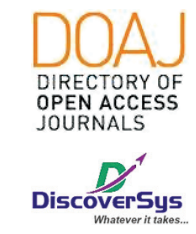

Published by DiscoverSys

\title{
Perbedaan manifestasi klinis dan laboratorium kolestasis intrahepatal dengan ekstrahepatal pada bayi di RSUP Sanglah Denpasar periode Januari 2015 - Desember 2018
}

\author{
Pande Putu Agung Willa Kesawa Putra, ${ }^{1 *}$ IGN Sanjaya Putra, ${ }^{2}$ \\ I Nyoman Budi Hartawan²
}

\section{ABSTRACT}

Introduction: Physiological jaundice found in infants and most symptoms are often mild. In conjugated jaundice defects in intrahepatic production, transmembran transport from bile, i.e. cholestasis intrahepatic, or extra-hepatic obstruction/cholestasis occur, resulting in bile barriers. This study was conducted to look at the differences in the clinical and laboratory manifestations of $\mathrm{IH}$ and $\mathrm{EH}$ cholestasis in infants. Method: A descriptive retrospective study was performed on 102 infants with cholestasis who came to Sanglah Hospital Denpasar, during the period of January 2015 - December 2018. Data analysis was performed with pearson Chi-square test and independent t-test. Result: Subjects consisted of 60 infants boys and 42 infant girls, intrahepatic cholestasis were 79 and extra-trahepatic cholestasis were
42. Significant differences in characteristic of nutritional status with intrahepatic and extra-hepatic cholestasis were found $(p=0,015)$, but there isn't significant differences in age, birth weight, gestational age were observed. On examination of stool color, there was a significant difference $(p<0,001)$, as well as laboratory results of SGOT, SGPT $(p<0,05)$ between intra and extra-hepatic cholestasis. Meanwhile there isn't significant differences in GGT, total bilirubin, direct bilirubin, indirect bilirubin, and ALP.

Conclusions: There were differences in the characteristics of nutritional status, differences in laboratory results of SGOT, SGPT, and fecal clinics between intrahepatic and extrahepatic cholestasis.
1Program Studi Pendidikan Dokter, Fakultas Kedokteran, Universitas Udayana, Bali-Indonesia ${ }^{2}$ Departmen/KSM IImu Kesehatan Anak, Fakultas Kedokteran, Universitas Udayana, BalliIndonesia

${ }^{*}$ Correspondence to: Pande Putu Agung Willa Kesawa Putra, Program Studi Pendidikan Dokter, Fakultas Kedokteran, Universitas Udayana, Bali-Indonesia pandekesawaputra@gmail.com

Diterima: 14-03-2019

Disetujui: 11-04-2019

Diterbitkan: 01-12-2019
Keywords: infant, jaundice, blood, laboratory.

Cite This Article: Putra, P.P.A.W.K., Putra, I.G.N.S., Hartawan, I.N.B. 2019. Perbedaan manifestasi klinis dan laboratorium kolestasis intrahepatal dengan ekstrahepatal pada bayi di RSUP Sanglah Denpasar periode Januari 2015 - Desember 2018. Intisari Sains Medis 10(3): 520-523. D0I: 10.15562/ism.v10i3.440

\section{ABSTRAK}

Latar Belakang: Ikterus fisiologis sering didapatkan pada bayi dan kebanyakan gejalanya ringan. Pada ikterus yang terkonjugasi terjadi defek produksi intrahepatal, transmembran dari empedu, yaitu kolestasis intrahepatal atau obstruksi kolestasis ekstrahepatal yang mengakibatkan hambatan empedu. Penelitian ini dilakukan untuk melihat perbedaan manifestasi klinis dan laboratorium kolestasis intrahepatal dengan ekstrahepatal pada bayi.

Metode: Studi ini menggunakan studi deskriptif restrospektif dilakukan pada 102 bayi dengan kolestasis yang dating ke Rumah Sakit Sanglah Denpasar, periode Januari 2015-Desember 2018. Analisis data ini dilakukan dengan uji pearson chi-square dan uji t-independen. Hasil: Subjek terdiri atas 60 laki-laki dan 42 perempuan, kolestasis intrahepatal sebanyak 79 orang dan ekstrahepatal sebanyak 23 orang.
Pada penelitian ini didapatkan perbedaan bermakna karakteristik status gizi antara kolestasis intrahepatal dan ekstrahepatal $(p=0,015)$, sedangkan usia, berat badan lahir, usia kehamilan tidak didapatkan perbedaan bermakna. Pada pemeriksaan warna feses didapatkan perbedaan bermakna $(p<0,001)$, demikian juga hasil laboratorium SGOT, SGPT, GGT didapatkan perbedaan bermakna $(p<0,05)$, sedangkan bilirubin total, bilirubin direk, bilirubin indirek, ALP tidak didapatkan bermakna.

Simpulan: Didapatkan perbedaan karakteristik status gizi, perbedaan hasil laboratorium SGOT,SGPT, dan klinis feses antara kolestasis intrahepatal dan ekstrahepatal.
Kata kunci: bayi, kuning, blood, laboratorium.

Cite Pasal Ini: Putra, P.P.A.W.K., Putra, I.G.N.S., Hartawan, I.N.B. 2019. Perbedaan manifestasi klinis dan laboratorium kolestasis intrahepatal dengan ekstrahepatal pada bayi di RSUP Sanglah Denpasar periode Januari 2015 - Desember 2018. Intisari Sains Medis 10(3): 520-523. DOl: 10.15562/ism.v10i3.440 


\section{PENDAHULUAN}

Kolestasis neonatal masih merupakan permasalahan di bidang ilmu kesehatan anak. Jumlah penderita kolestasis pada bayi dan anak semakin bertambah dari tahun ke tahun, dan sebagian penderita dengan kolestasis tersebut belum bisa ditegakkan diagnosisnya secara pasti. ${ }^{1}$

Kolestasis terjadi bila didapatkan hambatan sekresi berbagai substansi ke dalam duodenum, sehingga penghambatan ini menyebabkan bahan-bahan tersebut tertahan di dalam hati dan menimbulkan kerusakan sel-sel hati. Kolestasis didefinisikan sebagai penurunan aliran empedu karena gangguan sekresi oleh hepatosit atau obstruksi aliran empedu melalui saluran intrahepatik empedu atau ekstrahepatik empedu. ${ }^{2}$

Kolestasis pada bayi terjadi pada \pm 1:25.000 kelahiran hidup. Insiden hepatitis neonatal 1:5.000 kelahiran hidup, atresia billier 1:10.000-1:13.000. Rasio atresia bilier pada anak perempuan dan anak laki-laki adalah 2:1, sedang pada hepatitis neonatal, rasionya terbalik. ${ }^{3}$

Pada hasil penelitian di RSUP. Dr. Kariadi dari bulan Desember 2010 sampai Januari 2012 adalah sebanyak 29 kasus kolestasis, terdiri dari 19 lakilaki dan 10 perempuan. Sebagian besar berusia 0-2 tahun (66\%). Kasus yang belum terdiagnosis penyebab kolestasisnya sebanyak 10 anak (34\%), 19 anak didiagnosis kolestasis dengan berbagai penyebab yaitu 7 orang dengan infeksi cytomegalovirus (CMV), 4 orang dengan atresia bilier,

Tabel 1 Karakteristik kolestasis intrahepatal dan ekstrahepatal

\begin{tabular}{|c|c|c|c|}
\hline Variabel & $\begin{array}{c}\text { Kolestasis } \\
\text { Intrahepatal } \\
\mathbf{n}=79\end{array}$ & $\begin{array}{c}\text { Kolestasis } \\
\text { Ekstrahepatal } \\
\mathbf{n = 2 3}\end{array}$ & Nilai $p$ \\
\hline \multicolumn{4}{|l|}{ Jenis kelamin } \\
\hline Laki-laki & 48 & 12 & 0.462 \\
\hline Perempuan & 31 & 11 & \\
\hline \multicolumn{4}{|l|}{ Usia, bulan } \\
\hline$\leq 3$ bulan & 47 & 11 & 0.320 \\
\hline$>3$ bulan & 32 & 12 & \\
\hline \multicolumn{4}{|c|}{ Berat badan lahir (gram) } \\
\hline Normal & 53 & 16 & 0.823 \\
\hline$\leq 2500$ & 26 & 7 & \\
\hline \multicolumn{4}{|l|}{ Status Gizi } \\
\hline Gizi Baik & 29 & 9 & 0.015 \\
\hline Gizi Kurang & 48 & 9 & \\
\hline Gizi Lebih & 2 & 4 & \\
\hline \multicolumn{4}{|l|}{ Usia Kehamilan } \\
\hline Bayi Cukup Bulan & 56 & 19 & 0.262 \\
\hline Bayi Kurang Bulan & 23 & 4 & \\
\hline
\end{tabular}

2 orang dengan kolelitiasis, 1 orang dengan Alagille sindrom, 1 orang dengan limfoma, 1 orang hepatoma, 1 orang dengan Wilson disease, 1 orang dengan kista duktus koledokus, dan 1 orang dengan kolangitis. $^{1}$

Pada hasil penilitian di RSUP Sutomo Surabaya dari tahun 1999 sampai tahun 2004 dari 19270 penderita, didapatkan 96 penderita dengan neonatal kolestasis. ${ }^{2}$

Pada hasil penilitian di RSUP Sanglah Denpasar dari bulan Januari 2008 sampai September 2010 terdapat 787 bayi dengan kecurigaan sepsis dan didapatkan 355 bayi dengan hasil kultur darah positif, 265 bayi dengan hasil kultur darah negatif. Dari 355 bayi yang terbukti sepsis neonatorum, didapatkan 138 bayi $(38,9 \%)$ dengan kolestasis. ${ }^{4}$ Tujuan penelitian ini adalah mengetahui lebih dalam mengenai prevalensi dan karakteristik kolestasis serta perbedaan gambaran parameter laboratorium pada kolestatis intrahepatal dan ekstrahepatal.

\section{METODE}

Jenis penelitian ini adalah deskriptif-retrospektif yaitu rancangan penelitian yang hanya melakukan deskripsi mengenai data sekunder (rekam medis) yang sudah diperoleh sebelumnya. Penelitian ini dilakukan di Instalasi Rekam Medis RSUP Sanglah Denpasar selama Juli - Desember 2018. Dilakukan evaluasi terhadap karakteristik demografi dari anak, status gizi, usia, jenis kelamin, dan usia kehamilan. Parameter laboratorium seperti tes fungsi hati (SGOT dan SGPT), bilirubin direk dan indirek, bilirubin total, alkali pospatase, gamma-GT (GGT), dan konsistensi feses. Kemudian dari keseluruhan parameter tersebut dilakukan pengelompokan berdasarkan kolestasis intrahepatal dan ekstra hepatal. Analisis data dalam penelitian ini menggunakan bantuan program SPSS versi 25.0 untuk windows. Uji chi-square digunakan untuk mengetahui perbedaan diantara variabel kategorik dan uji t-independen digunakan untuk mengkaji perbedaan antara variabel numerik.

\section{HASIL}

Berdasarkan tabel 1 dapat diketahui bahwa terdapat 102 subjek kolestasis pada bayi yang terdiri atas kolestasis Intrahepatal sebanyak 79 bayi dan Ekstrahepatal sebanyak 23 bayi. Pada penelitian ini didapatkan subjek terbanyak adalah bayi laki laki. Subjek terbanyak yang dating ke rumah sakit pada usia $\leq 3$ bulan, status gizi baik 38 bayi, berat badan lahir normal 69 bayi, feses dempul 17 bayi dan bayi cukup bulan sebanyak 75 bayi. Didapatkan perbedaan bermakna antara status gizi pada kolestasis intrahepatal dan ekstrahepatal 
Tabel 2 Gambaran laboratorium dan feses pada kolestasis intrahepatal dan ekstrahepatal

\begin{tabular}{|c|c|c|c|}
\hline Variabel & $\begin{array}{c}\text { Intrahepatal } \\
\text { Kolestasis } \\
\mathbf{n}=72\end{array}$ & $\begin{array}{c}\text { Extrahepatal } \\
\text { Kolestasis } \\
n=23\end{array}$ & $\mathbf{p}$ \\
\hline \multicolumn{4}{|l|}{ Bilirubin Total } \\
\hline$(\mathrm{mg} / \mathrm{dL})$ & 9.39 & 9.76 & 0.841 \\
\hline Rerata(SB) & $(8.26)$ & $(5.72)$ & \\
\hline \multicolumn{4}{|l|}{ Direk bilirubin } \\
\hline$(\mathrm{mg} / \mathrm{dL})$ & 6.85 & 7.58 & 0.613 \\
\hline Rerata(SB) & $(6.53)$ & $(4.13)$ & \\
\hline \multicolumn{4}{|l|}{ Bilirubin Indirek } \\
\hline$(\mathrm{mg} / \mathrm{dL})$ & 1.85 & 1.35 & 0.832 \\
\hline Median(IQR) & $(2.56)$ & $(1.38)$ & \\
\hline \multicolumn{4}{|l|}{ SGOT } \\
\hline$(\mathrm{U} / \mathrm{L})$ & 170.09 & 184.70 & 0.042 \\
\hline Median(IQR) & $(190.90)$ & $(161.50)$ & \\
\hline \multicolumn{4}{|l|}{ SGPT } \\
\hline$(\mathrm{U} / \mathrm{L})$ & 46.10 & 86.40 & 0.031 \\
\hline Median(IQR) & $(126.48)$ & $(133.60)$ & \\
\hline \multicolumn{4}{|l|}{ GGT } \\
\hline$(\mathrm{U} / \mathrm{L})$ & 157.00 & 253.00 & 0.192 \\
\hline Median(IQR) & $(311.00)$ & $(605.00)$ & \\
\hline \multicolumn{4}{|l|}{ ALP } \\
\hline$(\mathrm{U} / \mathrm{L})$ & 340.52 & 409.17 & 0.216 \\
\hline Rerata(SB) & $(219.77)$ & $(273.20)$ & \\
\hline \multicolumn{4}{|l|}{ Feses } \\
\hline Normal & 75 & 10 & $<0.001$ \\
\hline Fluktuasi (dempul) & 4 & 13 & \\
\hline
\end{tabular}

$(\mathrm{p}=0,015)$, sedangkan karakteristik lain, yaitu jenis kelamin, usia, berat badan lahir dan usia kehamilan tidak didapatkan perbedaan bermakna.

Berdasarkan tabel 2, nilai SGOT secara seignifikan lebih tinggi pada kelompok anak dengan kolestasis ekstra hepatal dibandingkan dengan intra hepatal $(184,70$ Vs. 170,$09 ; \mathrm{p}=0,042)$. Nilai SGPT secara signifikan lebih tinggi pada kolestasis ekstra hepatal dibandingkan dengan intra hepatal $(86,40$ Vs 46,$10 ; p=0,031)$. Feses pada kolestatsis ekstra hepatal cederung lebih banyak dengan feses dempul yaitu sebanyak 13 bayi $(\mathrm{p}<0,001)$.

\section{PEMBAHASAN}

Hasil penelitian ini menunjukkan jenis kelamin terbanyak pada kolestasis adalah laki-laki, keadaan ini sama dengan penelitian di Bandung yang menunjukkan kelamin laki-laki menjadi terbanyak pada kolestasis. ${ }^{6}$ Jenis kelamin perempuan pada kolestasis ekstrahepatal pada penelitian ini lebih sedikit dari pada laki-laki, hasil ini tidak sesuai dengan penelitian yang dilaporkan Young dan Azzam. ${ }^{7}$ Usia subjek datang ke rumah sakit terbanyak pada usia $\leq 3$ bulan sebanyak 58 bayi. Status Gizi subjek terbanyak adalah gizi kurang sebesar 57 bayi. Usia kehamilan pada penelitian ini tidak menunjukkan adanya perbedaan bermakna antara kolestasis intrahepatal dan ekstrahepatal, sesuai dengan penelitian Omer dkk. ${ }^{10}$ Sedangkan pada warna feses seperti dempul didapatkan perbedaan bermakna antara kolestasis intrahepatal dan ekstrahepatal, keadaan ini sama dengan penelitian sebelumnya bahwa feses dempul dapat digunakan dalam mendiagnosis kolestasis ekstrahepatal. ${ }^{7}$

Pemeriksaan laboratorium tersebut untuk dapat menegakkan kolestasis pada penelitian ini seperti bilirubin total tidak didapatkan perbedaan bermakna antara kolestasis intrahepatal dan ekstrahepatal, hal ini berbeda dengan yang ditunjukkan pada penelitian Urganci dkk, sedangkan pada nilai bilirubin direk memperlihatkan hasil yang sama yaitu tidak bermakna pada penelitian Urganci dkk. ${ }^{9}$ Hasil penelitian ini memperlihatkan bahwa nilai SGOT dan SGPT adanya perbedaan bermakna antara kolestasis intrahepatal dan esktrahepatal, hal ini dinyatakan serupa pada penelitian sebelumnya dinyatakan bahwa hasil SGOT dan SGPT merupakan indikator yang sensitive terhadap kerusakan jaringan pada hepar, namun memiliki spesifisitas dan nilai prognosis yang kurang baik. ${ }^{10}$ Hasil laboratorium ALP serum pada penelitian ini tidak didapatkan peberdaan yang bermakna, hal ini serupa dengan penelitian. Sedangkan hasil laboratorium GGT didapatkan perbedaan yang bermakna, sedangkan pada penelitian lain didapatkan ALP dan GGT serum lebih tinggi secara bermakna pada kolestasis ekstrahepatal. ${ }^{6,11}$

Penelitian ini hanya menggunakan rancangan deskriptif retrospektif serta menggunakan jumlah sampel yang belum begitu besar, selain dari pada itu karakteristik lain seperti gambaran ultrasonografi tidak didapatkan dalam penelitian ini, tentunya keterbatasan tersebut mempengaruhi generalisasi dari penelitian ini.

\section{SIMPULAN}

Terdapat perbedaan karakteristik status gizi, sedangkan karakteristik lain tidak didapatkan perbedaan bermakna anatara kolestasis intrahepatal dan esktrahepatal. Sedangkan hasil laboratorium didapatkan perbedaan bermakna pada SGOT, 
SGPT, dan gambaran klinis feses antara kolestasis intrahepatal dan ekstrahepatal.

\section{PENDANAAN}

Penelitian ini tidak mendapatkan dana hibah dari pemerintah ataupun dari lembaga swasta lainnya.

\section{KONFLIK KEPENTINGAN}

Penulis menyatakan tidak terdapat suatu konflik kepentingan terkait publikasi dari artikel ini.

\section{ETIKA DALAM PENELITIAN}

Penelitian ini telah disetujui oleh Komite Etik Fakultas Kedokteran Universitas Udayana/RSUP Sanglah Denpasar dengan nomer referensi 1546/ $\mathrm{UN} 14.2 .2 / \mathrm{PD} / \mathrm{KEP} / 2018$

\section{DAFTAR PUSTAKA}

1. Kusumawati, dkk. 2012. Aspartat Amino TransferasePlatelet Ratio Index (APRI), Kadar Bilirubin dan Venektasi Penderita Kolestasis Anak di RSUP dr. Kariadi Semarang. Jawa Tengah: Media Medika Indonesia. 2012; 46(1): 57-61

2. Modha K. Clinical approach to patients with obstructive jaundice. Tech Vasc Interv Radiol. 2015.;18(4):197-200.
3. Arief S. Deteksi Dini Kolestasis Neonatal (Early Detection of Neonatal Cholestasis) [Internet]. Surabaya: Divisi Ilmu Kesehatan Anak FK Unari; 2006 [Diakses 10 Januari 2018]. Tersedia di: https://dokumen.tips/documents/deteksi-dini-penyebab-kolestasis-pada-bayi.html.

4. Karyana IPG, Putra IGNS, Yanti NPVK. Kolestasis pada Sepsis Neonatorum di RSUP Sanglah, Denpasar. Sari Pediatri. 2012;14(4):211-217.

5. Gaur K, Sakhuja P. Progressive familial intrahepatic cholestasis: a comprehensive review of a challenging liver disease. Indian J Pathol Microbiol. 2017;60(1):2-7.

6. Prasetyo D, Ermaya YS, Martiza I. Perbedaan manifestasi klinis dan laboratorium kolestasis intrhepatal dengan ekstrahepatal pada bayi. MKB. 2016;48(1):45-50.

7. Young S, Azzam R. Infatile cholestasis: approach and diagnostic algoritm. Textbook of pediatric gastroenterology, hepatology, and nutrition: a comprehensive guide to practice. Philadelphia: Saunders; 2016.

8. Omer M, Khattak TA, Shah SHA, Manzoor K. Etiological spectrum of persistent neonatal jaundice. JMRC. 2010;14(2):87-9

9. Urganci N, Cetinkaya F, Kalyoncu D, Cakir EDP. Infants with cholestasis:diagnosis, management, and outcome. Marmara Med J. 2012;2(1):83-6.

10. Bhatia, dkk. 2014. Management of neonatal cholestasis. Academy of Pediatrics. Indian Pediatrics. 2014;51:203-10.

11. Singh P, Khan S, Mittal R. Prevalence of jaundice based on liver function test in western nepal. Bali Medical Journal. 2013;2(2):72-74.

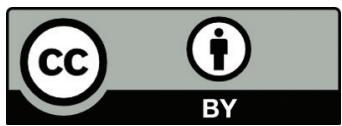

This work is licensed under a Creative Commons Attribution 